\title{
WILEY
}

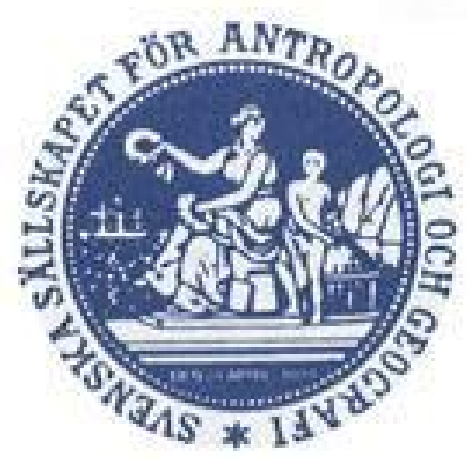

The National Geological Survey of China

Author(s): J. G. Andersson

Source: Geografiska Annaler, Vol. 3 (1921), pp. 305-310

Published by: Wiley on behalf of Swedish Society for Anthropology and Geography Stable URL: http://www.jstor.org/stable/519444

Accessed: 27-06-2016 07:17 UTC

Your use of the JSTOR archive indicates your acceptance of the Terms \& Conditions of Use, available at

http://about.jstor.org/terms

JSTOR is a not-for-profit service that helps scholars, researchers, and students discover, use, and build upon a wide range of content in a trusted digital archive. We use information technology and tools to increase productivity and facilitate new forms of scholarship. For more information about JSTOR, please contact support@jstor.org.

Wiley, Swedish Society for Anthropology and Geography are collaborating with JSTOR to digitize, preserve and extend access to Geografiska Annaler 


\section{THE NATIONAL GEOLOGICAL SURVEY OF CHINA.}

By F. G. ANDERSSON, PEKING.

T he young and progressive institution which carries the name "The Geological Survey of China" is a child of the Revolution which overthrew the Imperial regime of the Manchus and inaugurated the present Republican era. When at the end of IgI I the Provisional Government was formed at Nanking, Mr. H. T. Chang, a graduate of Tokyo University, was appointed chief of the section of Geology in the Department of Mines under the Board of Commerce and Industries, and in the following year he published in the Proceedings of the Geographical Society of China a program for a systematic geological survey of the country.

Upon the removal of the Central Government to Peking, Mr. Chang was appointed geological expert in the Ministry of Agriculture and Forestry. Shortly afterwards the two ministries became amalgamated as the Ministry of Agriculture and Commerce, and the section of geology of the Bureau of Mines came under the leadership of Dr. V. K. Ting, a pupil of the eminent British geologist, Professor J. W. Gregory of Glasgow.

When it was planned by Messrs. Chang and Ting to begin extensive geological field researches, a serious difficulty was encountered in the total lack of a staff of experienced field geologists. In his above-mentioned program for a national gelogical institute, Mr. Chang had proposed the establishment of a school for the training of surveying geologists, and this school was organized in September I9I3 with Mr. Chang as its Director.

The pupils were selected from amongst the graduates of middle schools, and the aim of the enterprise was to give to these young men a course of about three years intensive training in the branches necessary to a field gologist. It will be noticed that this "geological school" boldly replaced university training as it was then given; and the eminent success of the experiment will commend it to the interest of all colleagues of Messrs. Chang and Ting, who in other countries have tried to solve by different methods the difficult problem of recruiting a body of field geologists.

The teachers of the Geological School were mostly officials in the Ministry of Agriculture and Commerce, who during nearly three years persistently carried on 
these courses voluntarily and without any remuneration. Within an officialdom which by foreign writers is not infrequently spoken of with contempt as being devoid of patriotic sentiments, this patient and unostentatious work certainly stands out as a piece of splendid patriotism. I believe that it has never before been told in a foreign language how these representatives of Young China quietly but zealously worked for years to teach a still younger generation how to open up this immense country for geological research. It gives me a special pleasure

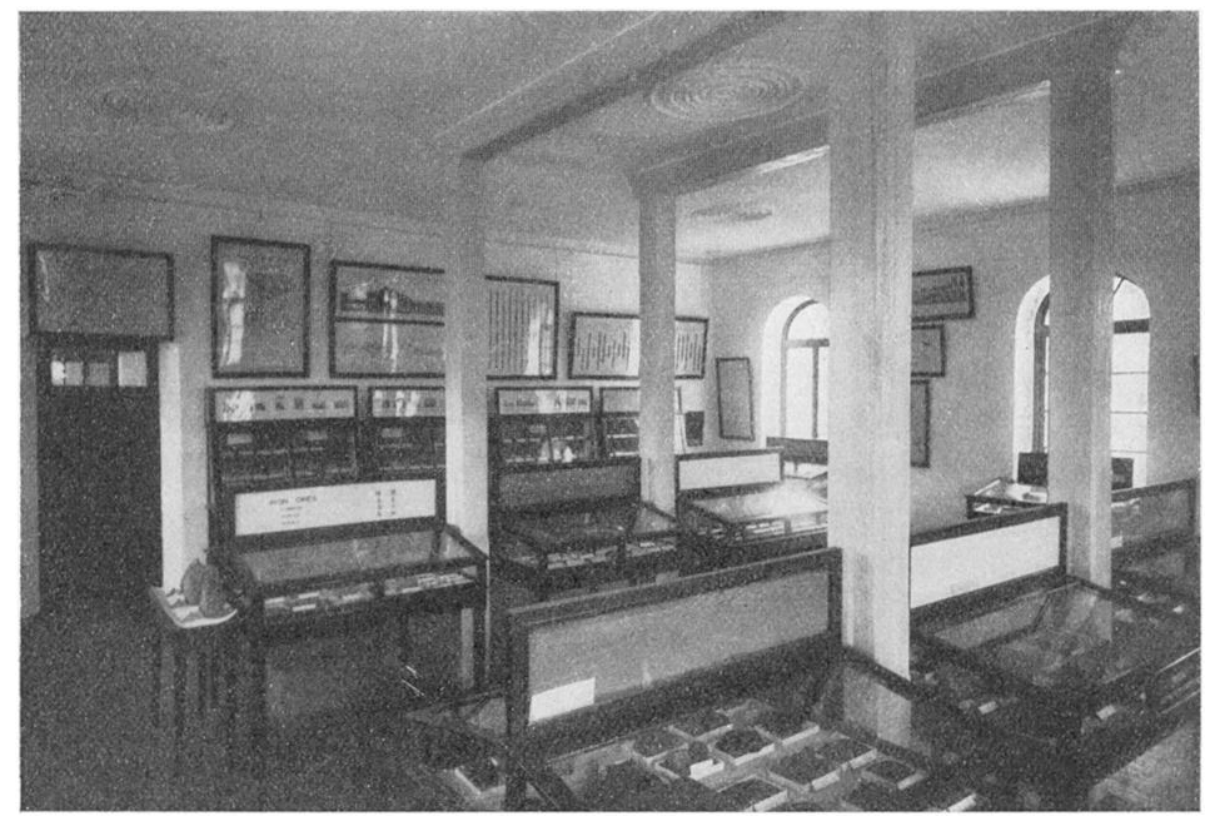

Fig. I. Museum of Geological Survey of China. Iron ores and coal.

to pay this tribute to the teachers of the Geological School, which is no longer in existence because it has fully accomplished its aim, which was to give the Geological Survey of China its first staff of efficient field men.

I will recall to mind these courses, which during the later terms were held in the premises of the present Geological Survey, where I also had my office. At every hour of the day, the bell rang for a change of teachers, and often, when I arrived to begin my day's work, I met one or other of my Chinese friends, who had just finished his first teaching hour for the day and who then went to his routine work in some office of the Ministry.

Besides Mr. Chang, the founder of the school, and Dr. Ting, the Director of the present Geological Survey, I want to mention among the tcachers Dr. W. H. Vong, 
a graduate of the University of Louvain, a charming man and distinguished scientist, our petrologist who in Dr. Ting's absence is acting Director of the Geological Survey.

Another most noteworthy member of the staff of teachers of the Geological School was Mr. Chang Yi-ou, M. E., educated in Mons. He was the first Director of the Department of Mines, a position so eminent that a holder of such a rank in title-ridden Europe would hardly dream of stepping down to become a teacher of youths. Yet, in this land of ceremonies and of formalism, this high mandarin, in rank next to a minister of State, walked quietly to his classes in metallurgy.

The subjects of study in the school were selected for the sole porpose of training geologists for the Survey. Besides pure and applied geology, including mineralogy, petrology and palæontology, with some short courses in biological sciences, the program included chemistry, physics, geodetic and topographic surveying, mining methods, the elements of metallurgy and some teaching of foreign languages.

The training was conducted not only in the school-room but also during numerous and trying field excursions. The average upper class Chinese is very little inclined to corporal exertions, but the writer of this article, who has travelled with educated Chinese of many types, can testify that the graduates of the Geological School have totally abandoned the sedan-chair and fully realize that a pair of strong legs is the field geologist's sovereign means of locomotion.

When the last term of the school neared its end, I was asked by the Minister of Agriculture and Commerce to undertake the examination of the 22 students, and I was permitted to conduct this in the form of an excursion in the Kaiping coal-basin, where we stayed ten days. During the first three days we went as one party all over the field, after which each student was given a week's time to examine a selected portion of the region in detail. To some was assigned a mine, to others a special group of strata, and to still others an examination of the industries based upon the minerals of the region.

After their reports, written in English, had been turned in, I had the pleasure, in consultation with the Director and the teachers of the School, to recommend the larger number of the graduates to promotion as junior members of the staff of the Geological Survey.

There is no doubt that the Geological School has proved a success. I have since carried on field work for months with a number of these young men. There are of course large individual differences; but these men are all serious and very active workers. A number of them have since been sent abroad, mostly to the United States, for additional training. One of them, who has recently left for the States, completed, before his departure, a monograph in English on the Western Hills of Peking, which is a piece of remarkably ripe and clear thinking, while at the same time it is a fine linguistic performance for a young fellow who had never been abroad. The paper is now in print and will soon be distributed. 
This article began with the statement that the Geological Survey was in its beginning a product of the revolution of I9II. In its present form, it is a creation of the Emperor-elect Yuan-Shih-Kai, who in 1916 was the centre of an attempt to restore the monarchy:

In 1915 the writer of this article had an opportunity, under the auspices of the then Minister of Agriculture and Commerce, Chow-Tzu-Chi, to explain, during a two hours audience, to President Yuan, and to illustrate by means of maps,

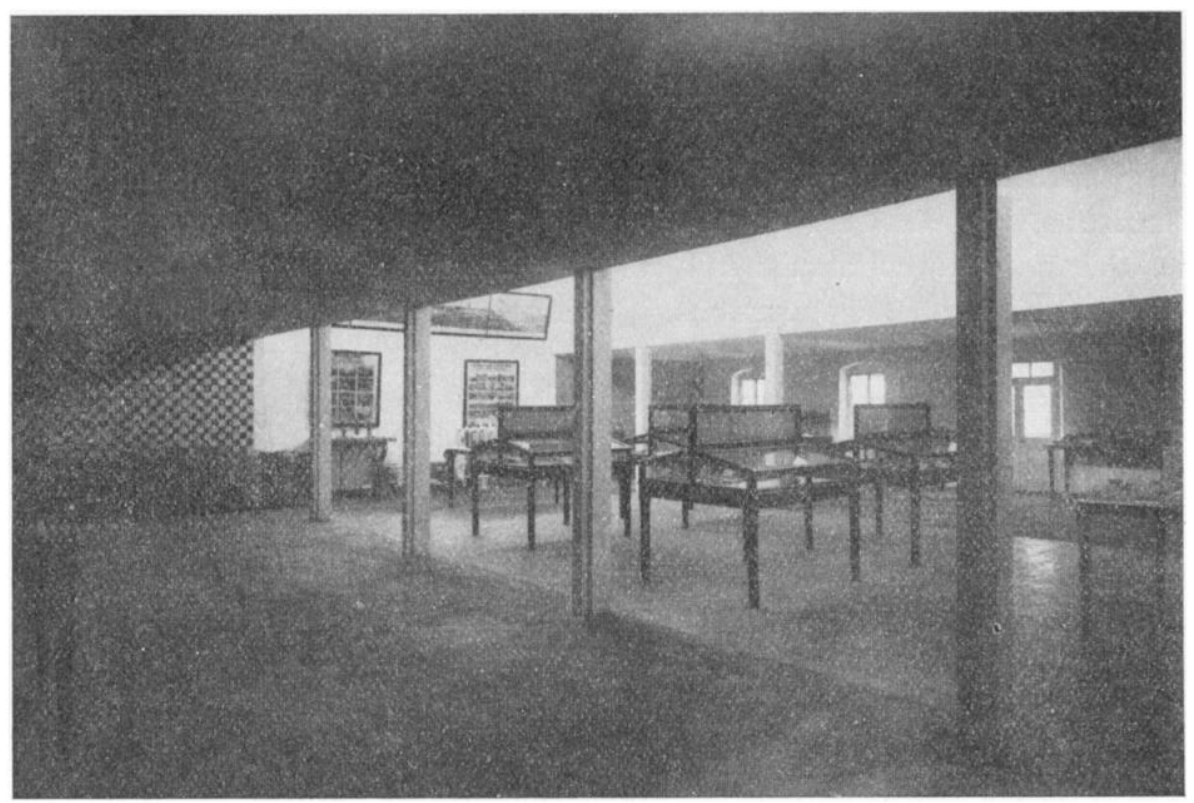

Fig. 2. Museum of Geological Survey of China. Non-Metalliferous deposits (except coal).

sections and numerous specimens, the result of our work, with reference to iron ore deposits. This demonstration remains for me a most remarkable memory, because of the deep impression I obtained of the powerful strength and penetrating genius of this man, who was then the almighty ruler of China. I believe that to some small extent it contributed to give to President Yuan a clearer understanding of the methods and possibilities of geological research.

The would be Emperor, Yuan, desired to enchance the splendor of his ascent of the Throne by creating a number of modern institutions, intended to promote industries and education. Orders to this effect were given to the different ministers, and in our Board a number of institutions were planned or created, amongst them an enlarged Geological Survey, with a considerable staff and a budget able to meet the necessary expenses. Some of Yuan's innovations have 
not materialized, because of the prolonged political struggle which followed upon his tragic downfall. But the Geological Survey has, under Dr. Ting's able and determined leadership, always enjoyed the full support of the men in power; and it has become such an important factor in the development of China's mineral resources that it may be safe to consider its continued growth full assured.

The staff of the Survey at present amounts to 30 persons, amongst them 18 field geologists. For practical reasons, the Ministry has very largely utilized the personnel for the examination of various kinds of mineral deposits, and a large number of ore bodies and coal fields have been surveyed in detail, on the scales of $\mathrm{I}: 20,000, \mathrm{I}: \mathrm{I0}, 000$ and larger scales. The iron-ore deposits have been made the object of special detailed research, and a monograph on the iron-ore resources of China prepared by Dr. F. R. Tegengren, who for a number of years was connected with the Survey, is ready for publication.

The general geological survey of the provinces of Chihli, Shantung and Shansi has also made considerable progress, and the geological description of the two last-named provinces will soon be completed. Surveys for China's paritcipation in the international geological map on the scale of $\mathbf{I}: \mathrm{I}, 000,000$ has recently begun.

Two series of publications have begun to appear, a Bulletin for smaller communications and Memoirs for larger monographic work. The first number of the Bulletin (IgIg) is available to the public as well as the first Memoir, in which Dr. Wong gives a summary of all available data on the mineral resources of China (metals and non-metals, except coal). In this work is contained a vast amount of information on the mineral deposits of China hitherto absolutely unattainable to foreigners. So far Dr. Wong's work is issued only in Chinese, but a French edition is planned to appear in the near future.

No distribution of the publications to Geological Surveys in other countries will take place before another, far advanced, memoir is fully completed.

The greatest difficulty for scientific work within the Survey has been the lack of literature. In the early part of this year the Director of the Survey succeeded in collecting from private donators, principally a number of mining companies, funds sufficient to start the establishment of an up-to date geological library. The building is under construction, and at the same time, the literature is being collected through many channels in Europe as well as in the United States of America.

Even in the early days of the Survey, a beginning was made in the establishment of a geological and palaeoritological museum. The larger part of the exhibition is devoted to the mineral resources of the country. In addition to a large section devoted to practical geology, there are small but comprehensive collections of the minerals of China, and of its igneous rocks and its fossils. The stratigraphic section is at present undergoing revision; and a section for dynamic geology has recently been organized. At present there are 2,850 specimens on 
exhibition, under glass and properly labelled, all collected in China by our own men.

A very considerable extension of the museum is contemplated within a few years, in order to put on exhibition the large series of animal and plant fossils which we have already collected, and which are at present in the hands of a number of specialists for monographic preparation.

It is not surprising that a geological Survey which is only few years old, and which has been kept busy with technical problems, has not yet had time to do much purely scientific research. But extensive and systematic collecting of fossils of all kinds has been carried on during a number of years, and several prominent coworkers have been secured for the examination of this material.

In I9I7 Dr. Th. G. Halle, keeper of the palaeobotanical department of the Stockholm Museum of Natural History, travelled extensively in this country collecting fossil plants. Since then we have continued the collecting, and at present Dr. Halle is engaged in the study of the very extensive material of Palaeozoic and Mesozoic floras thus brought together.

In I9I6 I began research work on the Caenozoic deposits of northern China, and in this connection a large number of fossil vertebrates, mostly mammals, have been brought together. As palaeontological collaborator for this material I have succeeded in securing the coooperation of another of my countrymen, Prof. Carl Wiman of Upsala, who is now engaged in preparing a monograph on the Hipparion fauna.

Recently Dr. A. W. Grabau, formerly Professor of palaeontology in Columbia University, New York, has come to China in the joint capacity of palaeontologist to the Geological Survey and Professor of palaeontology in the National University of Peking. , This eminent expert on invertebrate fossils has commenced work on the material, mostly of Palaeozoic age, which has been accumulated as the result of a number of seasons of field work.

It has been decided by the Director of the Survey to issue the monographs to be prepared by Messrs. Grabau, Halle and Wiman, as well as by other future palaentological co-workers, in a special publication entitled Palaentologia Sinica, which is intended to cover a series of independent monographs all the fossil faunas and floras of China Proper, as well as such material from the vast dependencies of China as may be brought together by the Survey. 